\title{
EU Competition Law Devours Its Children: The Proliferation of Anti-Competitive Object and the Problem of False Positives
}

\author{
Csongor István NAGY*
}

\begin{abstract}
In the last decade, EU competition law reached a major turning point in its history. Anti-competitive object became an elusive and unpredictable rule, which boosts the risk of false positives and has a significant chilling effect. This article analyses this metamorphosis and the social damages it is causing, and proposes an alternative conception. The article demonstrates that the emerging new concept of anti-competitive object erroneously conflates 'contextual analysis', which has been part of the objectinquiry from the outset, and 'effects-analysis', which has no role to play here. It submits that both doctrinal and policy reasons confirm that anti-competitive object should be a category-building principle of 'judicial rule-making' ('definition of the definition') and not applicable to individual arrangements directly.
\end{abstract}

Keywords: anti-competitive effect, anti-competitive object, competition analysis, effects analysis, EU competition law, per se illegality, rule of reason, US antitrust law

\section{INTRODUCTION}

Four decades ago, Robert H. Bork penned a seminal book on how competition law may suppress competition it is supposed to protect. ${ }^{1} \mathrm{He}$ called this the 'antitrust paradox'. His assessment was largely based on US antitrust law's shift to per se illegality. For a long time, it seemed that EU competition law would avoid this trap. The more 'economic approach', the ever-improved flexibility of the block exemption regulations, the endeavours to eliminate straitjacketing effects, and the de-bureaucratisation

* LLM, PhD, SJD, dr juris, research chair at the Centre for Social Sciences of the Eötvös Loránd Research Network; professor of law and head of the Department of Private International Law at the University of Szeged; recurrent visiting professor at the Central European University (Budapest/ Vienna/New York) and the Sapientia University of Transylvania (Romania). This article is based on research that the author carried out, as Braudel senior fellow at the European University Institute, Florence. The University's generous support is gratefully acknowledged. The author is indebted to Marcos Araujo Boyd, Zoltán Marosi, Professor Luc Peeperkorn and Professor Jules Stuyck for their comments. Of course, all views and any errors remain the author's own.

1 RH Bork, The Antitrust Paradox: A Policy at War with Itself (Basic Books, 1978). 
of competition enforcement all suggested that EU competition law was able to profit from the misfortunes of US antitrust. Unfortunately, these hopes proved to be vain.

In the last decade, EU competition law reached a major turning point in its history. Anti-competitive object became an elusive and unpredictable rule. New categories of anti-competitive object emerged and, in Allianz, ${ }^{2}$ the Court of Justice of the European Union ('CJEU') permitted competition authorities and Member State courts to deny the right to an effects-analysis, if they find the arrangement anti-competitive at first sight. The emerging new approach boosts the risk of false positives by allowing courts to condemn complex market practices quickly, without looking into the effects, and has a significant chilling effect. This suppresses practices that do not harm but benefit consumers.

This article analyses the metamorphosis of anti-competitive object ${ }^{3}$ and the social damages it is causing, and proposes an alternative conception. Part II gives a normative and somewhat idealised presentation of the pre-Allianz concept of anti-competitive object. Part III presents how Allianz changed and impaired object-analysis. Part IV presents the fluctuation of the new doctrine from ephemeral marginalisation to resurgence. Part V analyses the recently introduced category of 'information cartels' and how this notion overlooks the complexity of information exchanges. Part VI explains the difference between 'contextual analysis', the substantive examination embedded in the quest for anti-competitive object, and 'effects-analysis', which should have no role to play in this characterisation. Part VII contains the article's final conclusions and proposals.

According to the proposed doctrine, anti-competitive object is a category-building principle of 'judicial rule-making' ('definition of the definition') and not applicable to individual arrangements directly. In this scheme, anti-competitive object does not subject real agreements to a case-by-case assessment but creates a relatively clear list of categories (pigeonholes) that are pronounced outright prohibited (automatically condemned) and are offered no chance for justification under Article 101(1) of the Treaty on the Functioning of the European Union ('TFEU'). Accordingly, anti-competitive object works indirectly: it defines categories of automatically condemned restrictions and it is these categories that are actually applied in competition matters. In this sense, the relevant question is not if the arrangement is anti-competitive by object but if it comes under one of the categories of anti-competitive object (or calls for the creation of a new category). The object-inquiry is mainly 'textual' (that is, it focuses on the content of the agreement), however, it also embraces certain 'extra-textual' factors (circumstances going beyond the 'four corners' of the agreement). The article coins a new term to designate this legitimate extra-textual analysis ('contextual analysis'), which has been part of the object-inquiry from the outset, and demonstrates how this differs from the 'effects-analysis', which has no role to play here.

\footnotetext{
2 Allianz and others $v$ GVH, C-32/11, EU:C:2013:160.

3 See O Odudu, 'The Object / Effect Distinction' in N Charbit and S Ahmad (eds), Taking Competition Law Outside the Box: Liber Amicorum Richard Whish (Concurrences, 2020).
} 


\section{THE TRADITIONAL NOTION OF ANTI-COMPETITIVE OBJECT: AN IDEALISED PICTURE OF THE PRE-ALLIANZ CONCEPTION}

The pre-Allianz conception of anti-competitive object paralleled US antitrust law's per se illegality, with the important difference that automatic condemnation is limited to Article 101(1) TFEU and any agreement may, at least theoretically, benefit from an exemption under Article 101(3) TFEU. ${ }^{4}$ An agreement is per se illegal if it is always or almost always anti-competitive without any redeeming virtue. ${ }^{5}$ However, this implies, not nearly, that the court would scrutinise in individual cases whether the agreement is always or almost always anti-competitive without any redeeming virtue, ${ }^{6}$ since this part of the doctrine is not applied to 'flesh and blood' arrangements, it is merely used to create specific categories of automatically condemned agreements. ${ }^{7}$

In the same vein, anti-competitive object aimed to build categories and determined the 'definition of definitions'. It was not a judiciable principle used for case-by-case assessment but a principle of 'judicial rule-making' used to frame the development of the various categories (pigeonholes) of anti-competitive agreements (such as horizontal price-fixing, ${ }^{8}$ market-division, ${ }^{9}$ restriction of output, ${ }^{10}$ vertical resale price fixing ${ }^{11}$ and absolute territorial protection ${ }^{12}$ ). The function of anti-competitive object was not to subject real agreements to a comprehensive assessment but to create a relatively clear list of restrictions that are pronounced outright prohibited (automatically condemned) and are offered no chance for justification under Article 101(1) TFEU. The concept worked indirectly: it defined categories of automatically condemned restrictions and it was these categories that were actually applied in competition matters. In this thinking, the relevant question was not if the arrangement was anti-competitive by object but if it came under one of the categories of anti-competitive object.

The object-analysis was predominantly textual. The agreement's legal and economic context and background was relevant but merely in a limited set of

\footnotetext{
4 Matra Hachette, T-17/93, EU:T:1994:89, para 85; Beef Industry Development Society, C-209/07, EU:C:2008:643; GlaxoSmithKline, C-501/06 P, C-513/06 P, C-515/06 P, and C-519/06, EU: C:2009:610; Pierre Fabre, C-439/09, EU:C:2011:649. See Guidelines on Article 101(3) [2004] OJ C101/97, para 46; R Whish and D Bailey, Competition Law, $8^{\text {th }}$ ed (Oxford University Press, 2015), pp 127-29.

5 Northern Pac Ry Co v US, 356 US 1, 5 (1958).

6 For an alternative definition of anti-competitive object, see L Peeperkorn, 'Defining Restrictions "by Object”", September 2015, Concurrences No 3-2015, Art No 74812, p 49 (Those agreements are anti-competitive by object, which 'are (highly) unlikely to be used to create efficiencies'.).

7 Cf A Jones, 'Left Behind by Modernisation - Restrictions by Object under Article 101(1)' (2010) 6 European Competition Journal 649, pp 656-57.

8 See eg CB v Commission, C-67/13 P, EU:C:2014:2204, para 51.

9 See eg Toshiba $v$ Commission, C-373/14 P, EU:C:2016:26, para 28.

10 See eg Beef Industry Development Society, note 4 above, para 40.

11 SA Binon, 243/83, EU:C:1985:284, para 47.

12 Consten and Grundig, 56, 58/64, EU:C:1966:41.
} 
circumstance where they were needed to understand the arrangement's economic function and logic or to classify the agreement (horizontal or vertical). The idea to look, at times, into the context had nothing to do with the effects-analysis, which was limited to effect-type agreements. ${ }^{13}$ The lawyer could usually remain within the four corners of the contract, as the arrangement's economic logic could be comprehended without a contextual examination. This made anti-competitive object tremendously useful. One of its important merits was that it could be applied even with a rudimentary understanding of economics.

The tenet that it is unnecessary to look into the actual and potential effects implies that it is unnecessary to examine their surrogates (ie market circumstances) too. In competition analysis, certain circumstances, such as market power, are used as surrogates of effects. Quite often, it is not feasible or is extremely costly to prove the agreement's actual effects directly, but circumstantial evidence is available. In these cases, the restriction's anti-competitive potential and the undertakings' market power may prove anti-competitive effects with a sufficient level of certainty. This implies that the exclusion of effects-analysis, at the same time, rules out any requirement to define the relevant market and to ascertain the undertakings' market power.

Anti-competitive object ideally involves 'legal work' not encumbered by economics. Economic analysis secures better decisions (by mitigating the risk of false positives) but impairs predictability. Effect-type agreements are, in essence, 'it depends' agreements, which hinge on economic issues that are both unpredictable and extremely costly to break down. During the last 130 years, antitrust lawyers have made themselves comfortable with this exceptionally complex and uncertain modus operandi. This is the sacrifice competition law is making to avoid, or at least to minimise, false positives. This makes, however, clear-cut rules invaluable. The idea of anti-competitive object is based on the experience that there are cases where there is absolutely no need to engage in a costly effects-analysis, because the agreement is clearly restrictive of competition.

Anti-competitive object fits in the line of competition law's solutions that aim to give certainty to the system without questioning the basic tenet that in case of reasonable doubt a comprehensive effects-analysis needs to be carried out. Safe harbours (de minimis, block exemptions) single out those agreements that can be presumed to comply with competition law. In the same vein, anti-competitive object sets out the capital vices of competition law: it makes clear which agreements are outright prohibited and entail hefty fines (object-type agreements) and which are treated in a more relaxed manner (effect-type agreements).

13 The Horizontal Guidelines put this very clearly: '[i]t is not necessary to examine the actual or potential effects of an agreement on the market once its anti-competitive object has been established': Guidelines on the applicability of Article 101 to horizontal co-operation agreements [2011] OJ C11/1, para 24. See also Beef Industry Development Society, note 4 above, para 16 ('In deciding whether an agreement is prohibited by Article 81(1) EC, there is ... no need to take account of its actual effects once it appears that its object is to prevent, restrict or distort competition within the common market'.). 
Anti-competitive object's rationale determines the method of defining its categories. Automatic condemnation is limited to agreements that have an anti-competitive 'nature' ${ }^{14}$ Conceptually, anti-competitive 'by nature' refers to the notion that the serious anti-competitive potential of these agreements emerges from the agreement's characteristics and not from the joint effects of the agreement and circumstances extrinsic to the agreement (such as market power, market structure, and entry barriers). Put it otherwise, object-type agreements restrict competition no matter what the parties' market power and what the market's structure is, ${ }^{15}$ because it is the agreement itself that is restrictive of competition and not the agreement as it operates in the given circumstances. This is reinforced by the notion that agreements anti-competitive by object have, by definition, negative effects on competition and are prohibited irrespective of the circumstances. ${ }^{16}$ Although agreements between enterprises with a low market share may not be susceptible of harming competition, there is no point in tolerating these as 'impossible crimes', since they have no virtue at all. ${ }^{17}$

The division between 'object' and 'effect' is not determined by procedural convenience and is not a question of balancing between procedural costs and the expected costs of flawed decisions. Effects-analysis is the principle, and the distinction is meant to single out those arrangements where the effects-analysis is, indeed, needless and superfluous. Anti-competitive object is not based on a trade-off but on the absolute probability of false positives: it is reserved for those types of agreements that can be pronounced anti-competitive without any substantive risk of false positives.

\section{THE ALLIANZ DOCTRINE: A RE-CONCEPTUALISATION OF ANTI-COMPETITIVE OBJECT}

The CJEU's ruling in Allianz was the first case where the Court put aside the traditional categories of anti-competitive object and pronounced an unlisted agreement automatically condemnable on the basis of a case-by-case analysis.

The matter emerged from a serious regulatory failure in the Hungarian insurance market, which probably contributed to the ruling's oddity. Here, competition law was called upon to rectify an error outside its comfort zone. Two major insurance companies set selling targets for insurance brokers in the form of a percentage of the overall sales. A good part of these insurance brokers were repair shops, which had a dual role: they both provided repair services (covered by insurance) and sold insurance

\footnotetext{
14 Beef Industry Development Society, note 4 above, para 17. See O Odudu, 'Restrictions of Competition by Object - What's the Beef' (2009) 8 Competition Law Journal 11.

15 See CI Nagy, 'The Distinction between Anti-Competitive Object and Effect after Allianz: The End of Coherence in Competition Analysis?' (2013) 36(4) World Competition: Law and Economics Review $541, \mathrm{p} 553$.

16 See Expedia, C-226/11, EU:C:2012:795.

17 CI Nagy, 'The New Concept of Anti-Competitive Object: A Loose Cannon in EU Competition Law' (2015) 36(4) European Competition Law Review 154, p 155.
} 
products. As a financial incentive, the insurance companies offered higher hourly rates for repairs if the repair shop met the sales targets. The competition investigation focused on the vertical aspects of the foregoing arrangements, as there was no evidence suggesting a horizontal collusion.

Contrary to insurance agents, who are employed by the insurance company, brokers are neutral advisors, who are expected to serve the interests of the clients. Although they receive commission from insurance companies, they are not employed by them. The above financial incentives interfered with the role of the brokers. After the sectoral regulator had failed to intervene, the Hungarian Competition Office ('HCO') opened an investigation, pronounced these arrangements anti-competitive by object, and imposed astronomical fines. The case was referred to the CJEU in respect of hourly repair rates (but not in respect of the rest of the target fees). ${ }^{18}$

The CJEU confirmed the HCO's automatic condemnation and, by that, re-moulded the doctrine of anti-competitive object. In short, it held that any agreement may be regarded as anti-competitive by object if, after an abridged effects-analysis, the individual examination 'reveal[s] a sufficient degree of harm to competition' 19 and confirms that it is 'sufficiently injurious to competition'. ${ }^{20}$ This amounts to a paradigm shift: anti-competitive object no longer operates through the intermediation of categories but is viable in itself and, hence, provides for individual, case-by-case examination. After repeating the CJEU's settled case law, the Court's ruling went further and listed a set of factors completely unknown in the pre-Allianz era.

In order to determine whether an agreement involves a restriction of competition 'by object', regard must be had to the content of its provisions, its objectives and the economic and legal context of which it forms a part .... When determining that context, it is also appropriate to take into consideration the nature of the goods or services affected, as well as the real conditions of the functioning and structure of the market or markets in question. ${ }^{21}$

[T]hose agreements would also amount to a restriction of competition by object in the event that the referring court found that it is likely that, having regard to the economic context, competition on that market would be eliminated or seriously weakened following the conclusion of those agreements. In order to determine the likelihood of such a result, that court should in particular take into consideration the structure of that market, the existence of alternative distribution channels and their respective importance and the market power of the companies concerned. ${ }^{22}$

18 Although the case was tried solely on the basis of Hungarian competition law, the Hungarian Supreme Court considered Section 11 of the Hungarian Competition Act to be the equivalent of Article 101(1) TFEU and the legislative intent to follow the rules and principles of EU competition law could be established. The CJEU found that the preliminary question was admissible.

19 Allianz, note 2 above, para 34.

20 Ibid, para 46.

21 Ibid, para 36 (emphasis added).

22 Ibid, para 48 (emphasis added). 
This implies that an abridged effects-analysis needs to be carried out to ascertain whether the agreement has an anti-competitive object. The relevant factors (nature of the goods or services, 'the real conditions of the functioning' of the market, the structure of the market, presumably including absolute and relative market shares, and alternative distribution channels) are all circumstances that, at least in the pre-Allianz era, had been examined in the frame of the effects-analysis. As noted above, the proof of actual effects is usually costly and complicated (at times even unfeasible), hence, quite often, instead of direct proof, surrogates are used as circumstantial evidence. For instance, the agreement's anti-competitive potential and the parties' market power may, indirectly, prove actual impact. ${ }^{23}$

The ruling in Allianz raised various issues of conceptualisation, a part of which was settled by the subsequent case law. First, it was questionable if the new doctrine swept away the pre-existing categories of anti-competitive object and replaced them with a truncated effects-analysis. The subsequent case law confirmed that these traditional categories were not replaced but completed. Second, it was also questionable if the Court added a new item to the list of anti-competitive agreements by sowing the seeds of a new specific category. Later case law also confirmed that Allianz cannot be interpreted as merely creating a new category of vertical hardcore restraints but as re-defining anti-competitive object at large.

The subsequent case law corroborates that the most reasonable conceptualisation of Allianz is that it completed the list of object-type agreements with an open category. Thence, anti-competitive object is an open box made up of a set of specific agreements (traditional categories) and the unspecified category of unnamed objecttype agreements. Put it otherwise, the revisable but relatively closed list of agreements anti-competitive by object was turned into an illustrative list. An agreement coming under none of the specific categories may still be automatically condemned if, after an abridged effects-analysis, it is found 'sufficiently injurious to competition'.

\section{THE TRAJECTORY OF THE POST-ALLIANZ CASE LAW: MARGINALISATION AND RESURGENCE}

The Allianz doctrine was spelled out in a series of subsequent judgments. It was hoped that Allianz would remain an isolated ruling that was triggered by an odd fact pattern and a salient regulatory error, especially because in the first cases that reached the bench the CJEU (Cartes bancaires ${ }^{24}$ ), though confirming its validity, refused to condemn the arrangement at stake on the basis of the doctrine. ${ }^{25}$ Later

23 CI Nagy, 'The Distinction between Anti-Competitive Object and Effect after Allianz: The End of Coherence in Competition Analysis?' (2013) 36(4) World Competition: Law and Economics Review $541, \mathrm{p} 559$.

24 Groupement des cartes bancaires, C-67/13, EU:C:2014:2204.

25 Cf P Harper, 'Groupement des Cartes Bancaires Judgment - Rolling Back on the Expansion of by Object Infringements' (2014) 13 Competition Law Journal 321; MC Wahlin, 'Post-Cartes Bancaires: Restrictions by Object and the Concept of Vertical Hardcore Restrictions' (2014) 13 Competition 
on, in Maxima Latvija, the Court's argument even contradicted the conceptual pillars of Allianz. Nonetheless, in the end, these hopes proved to be vain: in Hoffmann-La Roche \& Novartis the doctrine re-appeared, untarnished, and reminded competition lawyers that it is an integral part of the legal test under Article 101(1) TFEU.

A. Reading Down Allianz: The Rulings in Cartes bancaires, MasterCard, Budapest Bank, and Maxima Latvija

Allianz was followed by a series of ruling (in Cartes bancaires, MasterCard, Budapest Bank and 'Maxima Latvija'), which confirmed the doctrine but disapproved the designation as anti-competitive by object in the given case. They might have even created the false pretence that the doctrine is so exceptional and its purview so much limited that it may be of little relevance for day-to-day practice.

In Cartes bancaires, French banks established an economic interest grouping in order to ensure the interoperability of the members' card-systems and to maintain the scheme's balance. The grouping introduced various measures to stimulate engagement in acquiring activities. One of these was a financial contribution paid by those banks who were less active in acquisition activities. Although confirming the Allianz doctrine ${ }^{26}$ the CJEU stressed that anti-competitive object has to be conceived narrowly, as it is the exception and not the rule, and it extents only to the most serious competition mischiefs that are, 'by their very nature', 'harmful to the proper functioning of normal competition, ${ }^{27}$ and 'reveal a sufficient degree of harm to competition that it may be found that there is no need to examine their effects' ${ }^{28}$

In MasterCard, ${ }^{29}$ the CJEU found that the multilateral interchange fee ('MIF') used in the bankcard system (paid by the acquiring bank, which operates the payment terminal, to the issuing bank, which issued the bankcard) is not anti-competitive by object. It held, with reference to Allianz, ${ }^{30}$ that in this context 'mere suppositions or assertions that the anti-competitive effects ... are 'obvious' cannot ... be relied upon' ${ }^{31}$ Although the question of object was not a pivotal issue, given that the MIF was assessed according to its effects and found restrictive, ${ }^{32}$ the judgment makes it clear that automatic condemnation should be restricted to arrangements whose restrictive effects are unequivocal.

Budapest Bank ${ }^{33}$ also dealt with the competition law characterisation of the MIF. The Hungarian Competition Office condemned Hungarian banks for fixing the

(F'note continued)

Law Journal 329; S Tannebaum, 'The Concept of the Restriction of Competition by Object and Article 101(1) TFEU' (2015) 22 Maastricht Journal of European and Comparative Law 138.

${ }^{26}$ Groupement des cartes bancaires, note 24 above, para 53.

27 Ibid, para 50.

28 Ibid, para 58; see also para 49.

29 MasterCard, C-382/12, EU:C:2014:2201.

30 Ibid, para 185.

31 Ibid, para 187.

32 Ibid, para 186.

33 Budapest Bank, C-228/18, EU:C:2020:265. 
domestic MIF and for treating the two payment card companies (VISA and MasterCard) alike as anti-competitive both by object and effect. ${ }^{34}$ The CJEU found that the MIF is presumed not to be anti-competitive by object. While concluding that this is a fact-intensive issue and, hence, the final decision is up to the national court, ${ }^{35}$ the Court also established a presumption against automatic condemnation. The wording of the preliminary decision makes this clear: it provides that the MIF is not anti-competitive by object, unless the national court finds that the arrangement's purpose and background suggests the opposite conclusion. ${ }^{36}$ It seems that the CJEU found that the preliminary question fell within the scope of the ruling in Cartes bancaires, where the Court took the same position with respect to another two-sided payment card system.

The Court stressed that anti-competitive object is the exception and not the rule and, hence, competition authorities and courts should make use of this only when there is sufficiently solid and reliable experience ('une expérience suffisamment solide et fiable') that bears out this conclusion. ${ }^{37}$ It may be assumed that such experience may derive from earlier case law or empirical analysis. ${ }^{38}$ The Court concluded that the experience with the MIF does not live up to this expectation. ${ }^{39}$

According to the CJEU, the following raised doubts as to the anti-competitive nature of the MIF. First, while acknowledging that indirect price-fixing is also pricefixing, ${ }^{40}$ the Court pointed out that banks did not fix the price but merely a cost element. ${ }^{41}$ Second, it also underlined that complex two-sided markets are normally not amenable to the automatic condemnation inherent to a finding that an agreement is anti-competitive by object. ${ }^{42}$ Third, the MIF appears to have been serving the purpose of creating balance in the system, which may be a legitimate consideration and may make the multilateral cooperation ancillary, and call for an effects-analysis. ${ }^{43}$ Fourth, the MIF was determined not by the sellers (issuing banks) unilaterally, but was based on a bipartite agreement between sellers and buyers (issuing and acquiring banks). Although the bipartite nature of the agreement does not rule out the existence of an anti-competitive object, it does raise doubts in this regard. ${ }^{44}$

\footnotetext{
34 MIF, Vj-18/2008.

35 Budapest Bank, note 33 above, para 59.

36 Ibid, para 86.

37 Ibid, para 76.

38 As later confirmed by the CJEU in the Lundbeck cases, the lack of prior judicial or competition authority condemnation does not rule out the characterisation of the agreement as anti-competitive by object, since this is not the only source of experience. Sun Pharmaceutical \& Ranbaxy, C-586/16 P, EU:C:2021:241, paras 85-86; Generics, C-588/16 P, EU:C:2021:242, paras 78-79; Lundbeck, C-591/16 P, EU:C:2021:243, paras 130-31; Xellia \& Alpharma, C-611/16 P, EU:C:2021:245, paras 118-21; Merck, C614/16 P, EU:C:2021:246, paras 97-100.

39 Budapest Bank, note 33 above, paras 65, 77, 79.

40 Ibid, para 62.

41 Ibid, para 61.

42 Ibid, para 68.

43 Ibid, paras 71, 73.

44 Ibid, paras 84-85.
} 
In 'Maxima Latvija', ${ }^{45}$ the CJEU encountered a question that, given the obvious answer, would have raised eyebrows in the pre-Allianz era. The Court was asked if a vertical non-compete clause is anti-competitive by object. Maxima Latvija rented commercial spaces in large malls and shopping centres and, as 'anchor tenant', it was granted the right to approve 'the lessor['s] letting to third parties commercial premises not let to Maxima Latvija ${ }^{46}$ As in the post-Allianz era virtually any agreement may be considered anti-competitive by object, the question was referred to the CJEU, which, not surprisingly, confirmed the obvious: vertical non-compete agreements are not anti-competitive by object and call for an effects-analysis. ${ }^{47}$

Most interestingly, the Court based its ruling on a textbook summary of the pre-Allianz conception of anti-competitive object, which called into question the cogency of the very doctrine established in Allianz. First, it underlined that the characterisation of the agreement as anti-competitive by object should be based on its 'content' (put it otherwise, the analysis should, in principle, remain within the four corners of the contract). ${ }^{48}$ Second, automatic condemnation is confined to cases where the agreement 'reveals in itself a sufficient degree of harm to competition' ${ }^{49}$ Even if demonstrated that the agreement 'could potentially have the effect of restricting' competition, this cannot imply that it always has such effects 'by [its] very nature', that is, irrespective of the market context. $^{50}$ This implies that the agreement's anti-competitiveness does not depend, among others, on the structure of the market and the parties' market shares. Third, the categories of anti-competitive object ('certain collusive behaviour') have to be defined on the basis of experience and not theoretical argumentation. ${ }^{51}$

The first and the second points, arguably, imply that market context does not have the relevance Allianz prescribes to it. The third point suggests that if neither the judicial practice, nor the literature has accumulated sufficient (empirical) experience about the arrangement at stake, it cannot be automatically condemned (cannot be pronounced anti-competitive by object) but an effects-analysis needs to be carried out. These contradictions make highly difficult to reconcile the rulings in 'Maxima Latvija' and Allianz.

\section{B. The Resurgence of Allianz: The Ruling in Hoffmann-La Roche \& Novartis}

For five years, the CJEU had not used the Allianz doctrine to condemn an arrangement falling outside the traditional categories of anti-competitive object. ${ }^{52}$ The first

\footnotetext{
45 'Maxima Latvija', C-345/14, EU:C:2015:784.

46 Ibid, para 5.

47 Ibid, paras 21, 23-24.

48 Ibid, para 17 ('Where, however, an analysis of the content of the agreement does not reveal a sufficient degree of harm to competition, the effects of the agreement should then be considered and, for it to be caught by the prohibition, it is necessary to find that factors are present which show that competition has in fact been prevented or restricted or distorted to an appreciable extent'.) (emphasis added).

49 Ibid, para 20 (emphasis added).

50 Ibid, para 22.

51 Ibid, para 19.

52 The Allianz ruling was adopted on 14 March 2013, while the ruling in Hoffmann-La Roche \& Novartis was adopted on 23 January 2018.
} 
(and so far only) case where this happened was Hoffmann-La Roche \& Novartis, ${ }^{53}$ where the Court condemned a horizontal conspiracy to divide the market by means of scare-mongering. However, instead of calling this foxy market-sharing by its name, it engaged in an obscure and amorphous demonstration about the agreement's anti-competitive nature. This perfunctory and unstructured analysis significantly impaired the judgment's doctrinal consistency: instead of construing market-division in light of the case, the Court provided a trivial reasoning that may even suggest that any agreement to engage in a communication campaign to distort customers' transactional decisions may be caught in the net of Article 101 TFEU (with the possibility to extend this, by analogy, to the unilateral acts of dominant undertakings).

The facts of the case revealed a complex form of market-sharing. Hoffmann-La Roche and Novartis marketed two competing drugs (Avastin and Lucentis). Even though these had virtually the same ingredients, they received marketing authorisation for different purposes: Avastin for oncological purposes, while Lucentis for eyediseases. ${ }^{54}$ Since Avastin was ten times cheaper than Lucentis, it became widely used off-label, to treat eye-diseases. ${ }^{55}$ In response to this, with the view of artificially differentiating between the two products and reducing their substitutability in the eyes of physicians and patients, the two undertakings launched a communication campaign asserting that Avastin raised safety risks if used to treat eye-diseases.

The CJEU found that the cooperation between Hoffmann-La Roche and Novartis had an anti-competitive object, because 'it is likely that the dissemination of such information will encourage doctors to refrain from prescribing that product, thus resulting in the expected reduction in demand for that type of use' ${ }^{, 56}$ and 'an arrangement that pursues the objectives (...) of [misleading both the regulators and the general public] must be regarded as being sufficiently harmful to competition to render an examination of its effects superfluous'. 57

Although the ruling could be read as suggesting that the cooperation was a 'cartel agreement', 58 neither the Court nor AG Saugmandsgaard Øe tried to subsume it under one of the existing categories. This makes it intensely difficult to ascertain the holding of the judgment. May any misleading communication carried out by two or more undertakings (under Article 101 TFEU) or a dominant undertaking (under Article 102 TFEU) that is capable of having a substantial effect on the competitive process violate EU competition law? It probably needs no explanation that such a principle would be odd and lead to extremely far-reaching consequences, especially because EU law already has a comprehensive regime addressing such

\footnotetext{
53 Hoffmann-La Roche \& Novartis, C-179/16, EU:C:2018:25.

54 Hoffmann-La Roche was granted marketing authorization (MA) concerning Avastin for oncological purposes, while Novartis acquired MA concerning Lucentis for ophthalmological purposes, such as macular degeneration and glaucoma.

55 Hoffmann-La Roche \& Novartis, note 53 above, para 46.

56 Ibid, para 93.

57 Ibid, para 94.

58 Ibid, para 80.
} 
issues: the Unfair Commercial Practices Directive ${ }^{59}$ ('UCP Directive') prohibits misleading business communication affecting consumers' transactional decisions. What role may antitrust law have besides the UCP Directive? While customers' informed decisions are key to the sound operation of the competitive process, is antitrust law, which has generally been regarded as tackling the repercussions of market power, really supposed to deal with this issue?

It is conspicuous that Allianz and Hoffmann-La Roche \& Novartis, the two cases where the amorphous conception of anti-competitive object has been applied to actually condemn an arrangement, have some odd similarities. Both cases centred around business practices that could earn no sympathy and aimed to cheat consumers. In Allianz, illicit financial incentives stimulated brokers to abuse the trust consumers placed in them. In Hoffmann-La Roche \& Novartis, false information was used to mislead consumers. Likewise, in both cases, the CJEU was called upon to rectify a serious failure of the sectoral regulation. Taking these into account, the two rulings raise far-reaching questions. Do they open a new chapter in EU competition law? Do they imply that, as a general principle, Articles 101 and 102 TFEU prohibit practices that impair consumers' chance to make informed decisions, given that such practices distort the competitive process?

It seems that instead of these far-reaching conclusions the ruling in Hoffmann-La Roche \& Novartis is nothing more than a very poorly reasoned condemnation of a horizontal market-sharing scheme. In fact, the ruling is the object-lesson of how the frivolous Allianz doctrine impairs the traditional categories of anti-competitive object. The CJEU could not see the forest for the trees. What Hoffmann-La Roche and Novartis were doing was a peculiar form of market-division, which is a traditional and settled category of anti-competitive object. ${ }^{60}$ Namely, the notion of market-division also encompasses arrangements that do not reach the level of an absolute ban. Besides straight promises not to sell outside a territory or to a group of consumers, market-sharing also embraces their functional equivalents, where competitors strive to reduce the substitutability of their products by means of disadvantaging outward sales or making inward orders from outside the allotted territory more difficult, for instance, by making them costlier or increasing customers' search costs. It amounts to market-division if two competitors, while not banning crosssupplies, agree to compensate each other via a fee for deliveries to the other undertaking's home country or they inform each other if they get an order from an

59 Directive 2005/29/EC concerning unfair business-to-consumer commercial practices in the internal market [2005] OJ L149/22.

60 Both drugs were developed by the Roche group but Novartis was entrusted with the commercial exploitation of Lucentis by means of a license agreement, hence, one may argue that this relationship was vertical. Nonetheless, although the Court was not explicit about the horizontal relationship between the parties, it did regard them, notwithstanding the licensing agreement, as competitors in relation to the post-license joint communication. It considered the arrangement not to be ancillary to the licensing agreement (para 75.) and the reason why it condemned it was that that it was put in place between 'two undertakings marketing two competing products' (paras 77 and 95.) in order to reduce the substitutability of these competing products and to diminish demand for Avastin in favor of Lucentis (para 93.). 
out-of-state customer and give time to the other undertaking to intervene. In the same vein, the promise not to make out-of-state advertisements (active sales), though not an absolute ban, may equally amount to market-sharing.

A quick look at the case law of US antitrust provides an array of examples of market-sharing arrangements that are short of an absolute ban. In US v Sealy ${ }^{61}$ and US v Topco, ${ }^{62}$ the parties were allowed to sell outside the territory allotted to them, the only restriction was that they could not use the Sealy and the Topco trademarks. In US $v$ Cooperative Theatres ${ }^{63}$ the parties agreed to abstain 'from actively soliciting each other's customers'. The US Court of Appeals ( $6^{\text {th }}$ Circuit) held that 'the so-called 'no-solicitation' agreement alleged in this case is undeniably a type of customer allocation scheme which courts have often condemned in the past as a per se violation of the Sherman Act'. The Court found 'it unnecessary to engage in the 'incredibly complicated and prolonged economic investigation' under the rule of reason standard where, as here, the alleged agreement is a 'naked restraint' with no possible pro-competitive justification'. In Blackburn and Green $v$ Sweeney and Pfeifer, ${ }^{64}$ two personal injury law firms agreed not to advertise in the other's territory, although their right to practice law was not restricted. The US Court of Appeals ( $7^{\text {th }}$ Circuit) considered the advertising restriction to be per se illegal market-division and held that ' $[\mathrm{t}] \mathrm{o}$ fit under the per se rule an agreement need not foreclose all possible avenues of competition'.

From an economic perspective, there seems to be no difference between these arrangements and the joint campaign of two competitors to reduce the substitutability of their products. In fact, under the circumstances, this was very likely the only way to isolate the two markets. It is most unfortunate that the CJEU, instead of elaborating the definition of market-sharing and its functional equivalents, summarily condemned the communication campaign and, thus, further impaired the consistency and predictability of object-analysis. The ruling is an object-lesson of how Allianz's oversimplified approach, void of the subtlety necessitated by the complexity of antitrust, blocks the development of well-established and entrenched categories of anti-competitive object and destructs competition law analysis.

\section{THE EXTENSION OF THE LIST OF NAMED CATEGORIES: 'INFORMATION CARTELS'}

The above re-moulding of anti-competitive object is part of a more general tendency. In parallel to the emergence of the Allianz doctrine, the Commission's 2011 Horizontal Guidelines declared an undefined cluster of horizontal information exchange anti-competitive by object. This was a strikingly new development, as

\footnotetext{
61 United States v Sealy, Inc, 388 US 350 (1967).

62 United States $v$ Topco Associates, 405 US 596 (1972).

63 United States $v$ Cooperative Theatres of Ohio, Inc, 845 F2d 1367 (6th Cir.1988).

64 Thomas Blackburn and Raymond T Green v Charles Sweeney, Jr and Daniel H Pfeifer, 53 F3d 825 ( $7^{\text {th }}$ Cir 1995).
} 
this characterisation found no reflection either in the earlier guidelines, or the scholarship. ${ }^{65}$ When doing so, the 2011 Guidelines set out two categories. The first one is defined and is made up of information exchanges concerning future prices and quantity. The second one is undefined and is made up arrangements whose anti-competitive object is corroborated by a case-by-case analysis extending to the totality of the circumstances. In essence, any arrangement may come under this category, with the exception of those which are specifically excepted (exchange of historical, statistical and genuine public data). ${ }^{66}$

The above category of anti-competitive object raises two very important problems.

First, it is worthy of note that this was not a judicial re-characterisation. In fact, it went against the CJEU's case law, which has never held information exchanges as such to be anti-competitive by object but placed them in one of the traditional boxes of anti-competitive object. All horizontal arrangements 'tampering with prices ${ }^{67}$ may easily amount to illegal price-fixing. ${ }^{68}$ In the same vein, disclosing future prices may imply an 'invitation to follow suit'. Furthermore, the Court held that even if an information exchange does not fit in one of the traditional categories, it may give rise to a stifling presumption that the undertakings engaged in hardcore concerted practice, ${ }^{69}$ by way of example, to fix the prices. In T-Mobile Netherlands, in the context of a horizontal exchange of pricing information (commissions paid to dealers), the CJEU pointed out that '[a]n exchange of information between competitors is tainted with an anti-competitive object if the exchange is capable of removing uncertainties concerning the intended conduct of the participating undertakings' ${ }^{70}$ It is settled case law, that if competitors exchange information concerning future prices, it is presumed that they act on the basis of this information, thus plunging into automatically condemned concerted practice. ${ }^{71}$ If the information exchange is systematic, it is virtually impossible to rebut this presumption. ${ }^{72}$

65 Guidelines on the applicability of Article 81 to horizontal cooperation agreements. [2001] OJ C3/2; R Whish, Competition Law (Oxford University Press, 2009), pp 118-20.

${ }^{66}$ Horizontal Guidelines, note 13 above, paras 89-90, 92-94.

67 US v Socony-Vacuum Oil Co, 310 US 150 (1940). ('Any combination which tampers with price structures is engaged in an unlawful activity'.).

68 Hüls, C-199/92 P, EU:C:1999:358, paras 160-61.

69 Suiker Unie, 40 to 48, 50, 54 to 56, 111, 113, 114/73, EU:C:1975:174, paras 173-74 ('[E]ach economic operator must determine independently the policy which he intends to adopt on the common market including the choice of the persons and undertakings to which he makes offers or sells. ... [The] requirement of independence does not deprive economic operators of the right to adapt themselves intelligently to the existing and anticipated conduct of their competitors, it does however strictly preclude any direct or indirect contact between such operators, the object or effect whereof is either to influence the conduct on the market of an actual or potential competitor or to disclose to such a competitor the course of conduct which they themselves have decided to adopt or contemplate adopting on the market'.) (emphasis added); Züchner v Bayerische Vereinsbank, 172/80, EU:C:1981:178, paras 14-15.

70 T-Mobile Netherlands, C-8/08, EU:C:2009:343, paras 41, 43.

71 Ibid, para 53.

72 See Anic Partecipazioni SpA, C-49/92 P, EU:C:1999:356, para 121; Hüls, note 68 above, paras $161-62$. 
Second, what is good in this category is not new, and what is new is not good.

The defined category of object-type information exchanges is made up of arrangements that, as noted above, had always been condemned as anti-competitive by object but not as information exchanges but as cartels. This is acknowledged by the 2011 Horizontal Guidelines themselves, when they provide that sharing future prices and quantity not only amounts to an information exchange anti-competitive by object but, at the same time, also qualifies as a genuine price-fixing and quantity cartel. $^{73}$

The 2011 Guidelines give no key to the construction of the undefined category, but try to explain it with a tautology. They simply provide that "[a]ny information exchange with the objective of restricting competition on the market will be considered as a restriction of competition by object ${ }^{\prime}{ }^{74}$ While the undefined category is not expected to have a specific meaning (after all, it is supposed to be applied on a case-by-case basis), it is expected to be accompanied by a clue that indicates the agreements it is meant to single out. On the contrary, the Guidelines essentially say that all arrangements that have an anti-competitive object are anti-competitive by object and try to cover up this tautology with a word-play. The subtle semantic difference between 'objective' and 'object' has no role in EU competition law, the two terms are, in this context, synonymous. This finds reflection is most of the language versions. ${ }^{75}$ The two terms have such a close meaning that, for instance, the Hungarian version uses the very same word for 'objective' and 'object' (even though Hungarian language also offers roughly synonymous expressions, like 'célzat').

This, again, leaves the fact-finder in a difficult position. On the basis of the content of the agreement it cannot be decided if the information exchange is anti-competitive by object, and an effects-analysis needs to be carried out. ${ }^{76}$ The Guidelines provide that this analysis extends to the 'legal and economic context in which the information exchange takes place'. ${ }^{77}$ It is very difficult to imagine how the arrangement could be classified without looking into the market.

All in all, it may be concluded that the exchange of future prices and quantities has always been condemned with the conceptual difference that the information exchange melted into the notion of price-fixing and quantity cartel. What is really new in the 2011 Horizontal Guidelines is that they created an undefined cluster of information exchanges that are anti-competitive by object and, hence, any arrangement may be automatically condemned (aside from the ones specifically excepted) after an abridged market-analysis.

\footnotetext{
73 Horizontal Guidelines, note 13 above, para 74.

74 Ibid, para 72 (emphasis added).

75 In the French version: 'objectif' and 'objet', in the German version: 'zum Ziel hat' and 'bezweckte Wettbewerbsbeschränkung', in the Romanian version: 'scop' and 'obiect', in the Spanish version: 'objetivo' and 'objeto'.

76 As to the complexities of the assessment of information exchange agreements, see M Bennett and P Collins, 'The Law and Economics of Information Sharing: The Good, the Bad and the Ugly' (2010) 6 European Competition Journal 311.

77 Horizontal Guidelines, note 13 above, para 72.
} 


\section{VI. 'CONTEXTUAL ANALYSIS' AND 'EFFECTS-ANALYSIS': THE PITFALL OF FALSE FRIENDS}

One of the major counter-arguments against the concept proposed by this article for the anti-competitive object is that the CJEU's judicial practices has been referring to the "legal and economic context ${ }^{78}$ as part of the object-analysis from the outset. ${ }^{79}$ Nonetheless, this 'context ${ }^{\circ 0}$ is quite different from the 'market context' that is inquired in the frame of effects-analysis.

In Société Technique Minière v Maschinenbau Ulm, ${ }^{81}$ the CJEU referred to 'context' as being potentially relevant but established that the characterisation as anti-competitive by object must be based on the content of the agreement and if the content itself reveals no anti-competitive object, a full effects-analysis needs to be carried out.

The fact that these are not cumulative but alternative requirements, indicated by the conjunction 'or', leads first to the need to consider the precise purpose of the agreement, in the economic context in which it is to be applied. This interference with competition referred to in Article 85(1) must result from all or some of the clauses of the agreement itself. Where, however, an analysis of the said clauses does not reveal the effect on competition to be sufficiently deleterious, the consequences of the agreement should then be considered and for it to be caught by the prohibition it is then necessary to find that those factors are present which show that competition has in fact been prevented or restricted or distorted to an appreciable extent. ${ }^{82}$

At first glance, this may appear to be contradictory: if characterisation is based solely on the agreement's content, why should context be relevant? This oscillation between 'content-analysis' and 'contextual analysis' has remained part of the ensuing practice. The CJEU's judgments confirming the doctrine laid down in Société Technique Minière $v$ Maschinenbau Ulm rephrased this as a content-analysis (which is exclusive) but still referred to context in regard to object-analysis. ${ }^{83}$

This begs the question: how to reconcile this reference to context with the tenet that characterisation is based on the content of the agreement and that, in case of an

78 See eg T-Mobile Netherlands, note 70 above, para 43.

79 Consten and Grundig, note 12 above, p 343; Société Technique Minière v Maschinenbau Ulm, 56/ 65, EU:C:1966:38, p 249.

${ }^{80}$ For an analysis on the case law on the 'legal and economic context, see Jones, note 7 above, pp 663-68.

81 Société Technique Minière v Maschinenbau Ulm, note 79 above, p 249.

82 Emphasis added.

83 Beef Industry Development Society, note 4 above, para 15; GlaxoSmithKline, note 4 above, paras 55, 58. As a recent example, in the Lundbeck cases, the CJEU re-confirmed that in the characterization as anti-competitive by object only the specific characteristics of the agreement (and not its effects in the market) are relevant and anti-competitive object can be inferred solely from these, even if the object-inquiry is carried out in view of the agreement's objectives and the economic and legal context. Generics, note 38 above, para 80; Lundbeck, note 38 above, para 131. 
anti-competitive object, no effects-analysis needs to be carried out (not even an abridged one)?

The most reasonable answer to this question is that the 'contextual analysis' enabled by the CJEU's jurisprudence and the 'effects-analysis' refer to different ways of analysis and do not overlap. Looking into the 'legal and economic context' does not necessarily imply an effects-analysis, as market-effects are not the sole context of the agreement. Even if the inquiry is limited to the agreement's content, in quite a few cases the characterisation cannot be carried out without looking into the context. The most conspicuous aspect that distinguishes 'contextual analysis' from effects-analysis is that the former is essentially legal work that extends to the factual context and can be carried out even with a rudimentary understanding of economics, while the latter requires economics expertise and extends to the market context. The purpose of the 'contextual analysis' is to interpret the agreement, comprehend its economic function and classify it (horizontal or vertical) and it can be carried out by means of traditional legal methodology.

By way of example, 'contextual analysis' is relevant in cases that hinge on ancillarity or where abusive references to effect-type agreements need to be screened out. There are various effect-type agreements that feature the elements of collusion. If they appeared 'naked', these agreements would qualify as anti-competitive by object. It is only the 'legal and economic context' that enables the fact-finder to ascertain if these elements are ancillary to a legitimate cooperation and, hence, they do not make the agreement a hardcore violation. Without a 'contextual analysis', it is impossible to distinguish naked price-fixing from joint production or commercialisation. If the fixing of the price is the only and single element, the agreement is 'naked' and, as such, anti-competitive by object. If economic activities are integrated by combining assets and exploiting synergies, an effects-analysis is warranted. Fortunately, most naked cartels are concluded in 'smoke-filled hotel room' scenarios and, hence, they are 'naked' beyond doubt. Nonetheless, undertakings may form, for instance, a sham commercialisation arrangement, which is meant to cover up a 'naked' cartel and involves no integration of economic activities. The requirement of an effects-analysis is not at the pleasure of undertakings but, without looking into the legal and economic context, the fact-finder would not be able to identify such abusive references. At the same time, automatically condemning all arrangements that involve some sort of a price-fixing would throw the baby out with the bathwater. The above distinction does not hinge on the effects in the market but on whether there is a genuine integration of economic activities (ancillary restraint) or the restraint, which the parties may eventually try to cover up with a frivolous reference to ancillarity, is 'naked'. The restraint may still be ancillary and call for an effects-analysis, even if the parties have market power, there are entry barriers and the market is concentrated. ${ }^{84}$

The CJEU's caselaw provides plentiful examples for a 'contextual analysis'. The most straightforward example is the distinction between horizontal and vertical agreements, which does call for an inquiry in the context.

84 Cf Odudu, note 3 above, pp 101-19, 115-17. 
In Generics, ${ }^{85}$ the Court held that a patent settlement, including reverse payments, calls for an effects-analysis if it is connected with a genuine patent dispute. This was confirmed in the Lundbeck cases ${ }^{86}$ which embraced six appeals emerging from the same competition matter. The pivot is ancillarity and not market context. Market structure, concentration, and power, as well as the impact on competition are all irrelevant at this stage of the analysis. Patent settlements may feature marketdivision, as one undertaking may promise not to enter another's market. If this is the agreement's only element (there is no legal dispute or there is one but it was designed to cover up the restraint), it is a 'naked' restraint. If market-division is linked to a genuine patent dispute, it is ancillary and, hence, not anti-competitive by object.

The same conceptual structure was used by the CJEU in Pierre Fabre ${ }^{87}$ and Coty, ${ }^{88}$ where, in the context of internet sales, it was established that restrictions objectively justified by selective distribution (ancillary restraints) are not anti-competitive by object, while, absent such a link to selective distribution, they are automatically condemned. These rulings suggest that selective distribution, if not objectively justifiable, is anti-competitive by object and this tenet applies to the individual restrictions too. ${ }^{89}$ Although this legal test involves a substantive examination, this has nothing to do with the effects-analysis.

The foregoing rulings dealt with cases involving commercial ancillarity. In Wouters,${ }^{90}$ the CJEU employed this approach in respect to a regulatory purpose pursued by the Dutch bar.

The above cases reveal that even though contextual analysis and effects-analysis address substantive aspects, going beyond the four corners of the contract, they are completely different both in terms of focus and methodology. The former does not deal with market context but circumstances that can be examined through traditional legal means. Contextual analysis is a 'lawyers' job' and is no different from cases where the law invalidates technically lawful contracts that aim to circumvent a legal prohibition or fall foul of good morals. Contextual analysis is very different from the economics analysis involved in the assessment of the market, the actual and potential consequences and their surrogates.

Allianz does not define the purpose and ambit of the inquiry into the legal and economic context and blurs the line between contextual and effects-analysis. This is

85 Generics, C-307/18, EU:C:2020:52. See B Zelger, 'By Object or Effect Restrictions - Reverse Payment Settlement Agreements in light of Lundbeck, Servier, and Generics' (2020) 12(4) Journal of European Competition Law and Practice 273.

${ }^{86}$ Sun Pharmaceutical \& Ranbaxy, note 38 above, paras 68-71; Generics, note 38 above, paras 66-69; Lundbeck, note 38 above, paras 112-15; Arrow, C-601/16 P, EU:C:2021:244, paras 71-75; Xellia \& Alpharma, note 38 above, paras 96-99; Merck, note 38 above, paras 84-88.

87 Pierre Fabre, note 4 above.

88 Coty, C-230/16, EU:C:2017:941.

89 Pierre Fabre, note 4 above, para 39; Coty, note 88 above, para 24.

90 Wouters, C-309/99, EU:C:2002:98. For a conceptualisation of the ruling, see R Nazzini, 'Article 81 EC between Time Present and Time Past: A Normative Critique of "Restriction of Competition" in EU law' (2006) 43 Common Market Law Review 521. 
exacerbated by the Commission's 2011 Horizontal Guidelines which provide that horizontal joint selling agreements 'are ... likely to restrict competition by object' but fail to specify why and when. The explanation that these agreements 'have the object of coordinating the pricing policy of competing manufacturers or service providers ${ }^{, 92}$ is both inconsistent and useless. Namely, it is not the price-fixing as such but the lack of ancillarity that may make these arrangements anti-competitive by object. Every arrangement involving joint productive activities may easily involve price limitations, hence, it is of little help to say that tampering with prices may make them anti-competitive by object. What may make these arrangements anti-competitive by object is not that they tamper with prices but that they are not ancillary, because they do not involve a genuine integration of economic activities.

The ensuing maze is very well exemplified by the EFTA Court's judgment in $S k i$ Taxi,${ }^{93}$ where, surprisingly, it held that it depends on an undefined set of circumstances, if a consortium is anti-competitive by object, and the fact that the parties define a common price (which is inevitable if making a joint offer) tilts the balance of probabilities towards anti-competitive object. ${ }^{94}$ According to the EFTA Court, a consortium and a joint bid involving the integration of economic activities may be anti-competitive by object, if it 'reveals a sufficient degree of harm' taking into account 'the substance of the cooperation, its objectives and the economic and legal context of which it forms part' ${ }^{95}$ Hence, anti-competitive object is a factual issue, which requires a detailed examination and a case-by-case assessment of the market. ${ }^{96}$

Sadly, the judgment brings back two notorious 'Justizmords' of US antitrust law from half-century ago. In US v Sealy ${ }^{97}$ and $U S v$ Topco, ${ }^{98}$ SMEs engaged in joint productive activities and created collective trademarks, which they licensed to members on an exclusive basis. In the since-then overruled judgments, the US Supreme Court found that these arrangements amounted to per se illegal market-sharing. Since then, it has become a truism that these judgments stifled clearly procompetitive arrangements and suppressed competition in the name of competition. ${ }^{99}$ The integration of economic activities, such as joint production and commercialisation, cooperatives, and collective trademarks, may very naturally involve price limitations and territorial restrictions, but have nothing to do with 'naked' restraints. The examination of these schemes comes to a fork in the road at the early stage of the competition analysis, where it needs to be decided if they are automatically

\footnotetext{
91 Horizontal Guidelines, note 13 above, para 234.

92 Ibid, para 234.

93 Ski Taxi, E-3/16, [2016] EFTA Ct Rep 1002.

94 See IH Anchustegui, 'Joint Bidding and Object Restrictions of Competition: The EFTA Court's Take in the Taxi Case' (2017) 1 European Competition and Regulatory Law Review 174.

95 Ski Taxi, note 93 above, para 101.

96 Ibid, para 95.

97 United States v Sealy, Inc, 388 US 350 (1967).

98 United States $v$ Topco Associates, note 62 above.

99 RH Bork, The Antitrust Paradox: A Policy at War with Itself (Basic Books, 1978), pp 274-78.
} 
condemned. Here, the relevant question is whether they involve a genuine integration of economic activities. If they do, they qualify as effect-type agreements (even if some circumstances, for instance, the size of the undertakings, are claimed to foreshadow the outcome of this effects-analysis). The genuine integration of economic activities is certainly not always or almost always anti-competitive, hence, unless it is a sham, it cannot 'reveal a sufficient degree of harm'. Evidently, the fact that the effects-analysis corroborates anti-competitive effects does not imply that the agreement is ab ovo anti-competitive by object.

\section{CONCLUSIONS AND CLOSING THOUGHTS}

The last decade has seen the profound transformation of anti-competitive object in EU competition law. As a result of the CJEU's ruling in Allianz and the ensuing case law, anti-competitive object became an elusive concept which enables automatic condemnation after an abridged effects-analysis. The Allianz doctrine, without offering any redeeming virtue, seriously impairs the consistency and predictability of competition analysis and significantly increases the risk of false positives. The doctrine conflates 'contextual analysis', which is a natural part of object-inquiry, and 'effects-analysis', which should have no role to play in the quest for the agreement's object. As a consequence, the Allianz doctrine disturbs competition law's doctrinal compass and, by increasing the risk of 'friendly fire', may suppress the very competition it is supposed to foster.

This article demonstrated that the above goes against the very rationale of anti-competitive object. This rationale warrants a category-building principle of 'judicial rule-making' ('definition of the definition'), which is not applicable to individual arrangements directly. The article's proposal is underpinned by both doctrinal and policy arguments.

On the doctrinal side, the conceptual considerations emerging from the notion of anti-competitive object suggest that this category is confined to agreements that are anti-competitive in themselves, that is, the restriction of competition results from the agreement and not from the interaction between the agreement and market circumstances. Those agreements are anti-competitive by object that have an anti-competitive nature. This implies that these agreements' anti-competitiveness emerges from the very characteristics of the agreement and not from the joint effects of the agreement and extrinsic circumstances (such as market power, market structure, and entry barriers).

On the policy side, the proposed conception has compelling practical merits: it rules out (or at least minimises) false positives, as it limits automatic condemnation to agreements whose assessment is backed by extensive experience and have proved to be always or almost always anti-competitive. This keeps erroneous decisions to the minimum and also obviates undertakings' self-censorship. Although it generates somewhat higher enforcement costs than the elusive Allianz doctrine, these are dwarfed by the social damages it avoids (in comparison to the latter). Finally, it should not be overlooked that EU competition law is applied in a decentralised system. Given that it involves national competition authorities and courts with varying levels of 
competition law expertise, this exacerbates the risk of false positives inherent in the elusive Allianz doctrine.

The cost-benefit analysis of anti-competitive object is essentially governed by two considerations: the desire to avoid false positives and to save unnecessary enforcement costs. False negatives are not a major issue here, as agreements that do not come under the scope of anti-competitive object can still be condemned by means of an effects-analysis. The relationship between these two considerations features, however, no balancing, because cost-saving comes into picture only if it does not increase the risk of false positives. This is why anti-competitive object is expected to suppress merely those arrangements that are always or almost always anti-competitive (without any redeeming virtue).

Competition law's analytical structure, the legal tests and the burden of proof are all set in a way that minimises false positives and negatives. The effects-analysis, which carries the day in most matters, is extremely costly and burdensome. Still, the desire to obviate erroneous decisions prevails and the need for a complex effects-analysis is done away with solely in cases where the risk of erroneous decisions is insignificant. EU competition law's all clear-cut rules feature this notion. The safe harbours of de minimis and block exemption exempt agreements that are certainly in accordance with the requirements of competition law; these safe harbours are not open to agreements that are 'merely' very unlikely to be anti-competitive. If there is reasonable doubt, the agreement needs to be inspected in detail. In the same vein, automatic condemnation is limited to agreements that are always or almost always anti-competitive, without the perspective of a redeeming virtue. ${ }^{100} \mathrm{~A}$ detailed effects-analysis is warranted, even if it is more likely than not that the agreement is anti-competitive. Anti-competitive object was not designed for 'suspect' agreements but for incorrigible ones.

The main risk attached to anti-competitive object is over-enforcement (false positives). This is why the scope of automatic condemnation has been kept to the minimum on both sides of the Atlantic. It is generally understood that the social costs of an overly wide ambit clearly outweigh the procedural convenience and reduction in enforcement costs. The temptation that often captures competition authorities and courts is fuelled by the fact the difference between the two are at times positive on the individual but negative on the social level. The over-simplified approach of Allianz saved the competition authority significant enforcement costs in a case where the effects-analysis was not expected to deliver an opposing conclusion. However, this came at horrendous costs on the side of false positives. These costs are made up of potential over-enforcement in other cases (where the outcome of an effects-analysis is not so certain) and of self-censorship in cases where the parties abstain from engaging in legitimate cooperation because they do not want to run the risk of being hit by a loose cannon.

100 Jones, note 7 above, p 655. 